\title{
IMPLEMENTASI TAX PLANNING MELALUI PEMANFAATAN GREY AREA PERPAJAKAN UNTUK PENGHEMATAN PPh TERUTANG
}

(Study Kasus Pada Perusahaan "X”)

\author{
Yanuar Lazuardi 1
}

Fakultas Ekonomi, Universitas Islam Lamongan

yanuarlazuardi@unisla.ac.id

Aris Nur Rakhmayani ${ }^{2}$

Fakultas Ekonomi, Universitas Islam Lamongan

ayisarisaja@gmail.com

\begin{abstract}
Abstrak
Penelitian ini dilakukan untuk mengkaji grey area dalam peraturan perpajakan yang berlaku. Grey area dalam peraturan perpajakan berpotensi dimanfaatkan wajib pajak untuk mendapatkan penghematan pembayaran pajak, melalui tax planning. Grey area perpajakan adalah keadaan, transaksi atau kejadian yang dicurigai atau diindikasikan akan terekspos oleh peraturan perpajakan, akan tetapi tidak ada peraturan perpajakan yang berlaku saat ini yang bisa diterapkan terhadap hal tersebut. Grey area perpajakan dapat terjadi pada aturan dalam ketentuan umum dan tata cara perpajakan (KUP), pajak penghasilan (PPh), dan pajak pertambahan nilai (PPN). Penelitian ini membatasi pembahasan pada grey area dalam ketentuan peraturan pajak penghasilan (PPh). Penelitian ini diharapkan bisa menjelaskan kepada wajib pajak tentang aturan dalam pajak penghasilan yang termasuk grey area atau tidak. Aturan-aturan yang bersifat grey area berisiko untuk diimplementasikan jika tidak memiliki landasan pemahaman yang kuat terhadap aturan yang ada, akan tetapi sayang untuk dikesampingkan. Pemahaman terhadap tax planning atas grey area perpajakan dan implementasinya dapat menghemat pembayaran pajak perusahaan. Kesalahan dalam implementasi tax planning atas grey area perpajakan termasuk kategori tax evation sehingga dapat disidik oleh otoritas pajak, diterbitkannya surat ketetapan pajak kurang bayar (SKPKB) dengan disertai denda dan atau sanksi administrasi perpajakan lainnya yang berakibat pemborosan sumber daya perusahaan. Penelitian ini menggunakan pendekatan kualitatif dengan metode study kasus pada Perusahaan " $X$ ". Hasil dari penelitian ini adalah perusahaan telah berupaya menerapkan tax planning dalam memenuhi kewajiban perpajakannya akan tetapi tetap dalam bingkai aturan perpajakan yang ada (tax avoidance). Upaya implementasi tax planning melalui pemanfaatan grey area perpajakan memiliki manfaat yang positif bagi perusahaan yakni perusahaan memperoleh manfaat berupa efisiensi pembayaran pajak penghasilan, sehingga dapat memaksimalkan income after tax perusahaan.
\end{abstract}

Kata Kunci : Pajak Penghasilan (PPh), tax planning, grey area, penghematan pajak 


\section{PENDAHULUAN}

Grey area adalah wilayah abu-abu yang berpotensi ditafsirkan berbeda oleh banyak orang. Agar tidak semua persoalan menjadi grey area, maka cara penafsiran dan prinsip penafsiran yang benar harus diterapkan terlebih dahulu sebelum menyikapi suatu permasalahan (Binsarjono,2008:5). Hal tersebut tidak dapat dipungkiri karena manusia adalah makhluk ciptaan Tuhan yang unik, yang memiliki keragaman antara yang satu dengan yang lainnya. Grey area dapat diartikan sebagai (Bsinsarjono,2008:23): 1) Area yang berada diantara dua wilayah, A atau wilayah B. Area itu tidak bisa dipastikan posisinya apakah berada diwilayah $\mathrm{A}$ atau wilayah $\mathrm{B}, 2$ ) Aktivitas atau tindakan yang tidak diatur oleh peraturan,

3) Aturan yang diinterpretasikan secara berbeda-beda oleh berbagai pihak, 4) Batas antara dua hal yang masing-masing tidak bisa, sulit atau tidak mungkin didefinisikan dengan jelas, dan batas ini cenderung berubah dan bergeser dari waktu ke waktu, 5) Wilayah dimana tidak ada aturan yang jelas, baik aturan yang ada atau aturan sebelumnya, atau wilayah dimana aturan sudah sedemikian lama tidak diterapkan, sehingga tidak terlalu jelas apakah masih bisa diterapkan atau tidak. Salah satu permasalahan yang rawan ditafsirkan berbeda oleh setiap orang adalah peraturan perpajakan. Setiap kalimat dalam peraturan perpajakan adalah bahasa hukum, yang dapat diartikan bermacam-macam bila ditafsirkan oleh pihak-pihak yang memiliki kepentingan berbeda. Oleh karena itu, wilayah abu-abu atau yang sering disebut dengan grey area erat kaitannya dengan kehidupan setiap orang.

Tax planning atau yg bisa disamakan maknanya dengan tax avoidance adalah: rekayasa "tax affair" yang masih tetap berada dalam bingkai ketentuan perpajakan yang berlaku (lawful), yang mana tax avidance dapat terjadi (ditemui) di dalam bunyi ketentuan/tertulis di undang-undang dan berada dalam jiwa (spirit) dari pada Undang-Undang tersebut (Suandy,2001;8). Tax planning adalah suatu cara yang dapat ditempuh oleh Wajib Pajak untuk menekan seminimal mungkin jumlah pajak terutangnya tetapi tetap berpedoman dan berdasarkan pada peraturan perpajakan yang berlaku untuk mendapatkan optimalisasi income after tax bagi perusahaan. Type karakter dalam tax planning ditujukan untuk memperoleh likuiditas dan laba yang memadai, yang dapat diimplementasikan melalui beberapa cara, salah satunya adalah melalui pemanfaatan wilayah abu-abu yang ada dalam peraturan perpajakan atau yang sering disebut dengan grey area perpajakan. Grey area perpajakan adalah: keadaan, transaksi atau kejadian yang dicurigai atau diindikasikan akan terekspos oleh peraturan perpajakan, akan tetapi tidak ada peraturan perpajakan yang berlaku saat ini yang bisa diterapkan terhadap hal tersebut (Binsarjono,2008:31). Grey area perpajakan dapat terjadi dalam ketentuan umum dan tata cara perpajakan (KUP), pajak penghasilan $(\mathrm{PPh})$, dan pajak pertambahan nilai (PPN). Dalam konteks perpajakan, grey area memiliki beberapa karakteristik, antara lain: 1) Keadaan atau transaksi yang sebenarnya terekspos pajak, akan tetapi tidak ada aturan yang mengaturnya. 2) Ada aturan tapi tidak jelas karena tidak lengkap, tidak implementatif, memunculkan multi tafsir, berbeda antara aturan dengan praktek dan sebagainya. 3) Ada aturannya, akan tetapi jumlahnya lebih dari satu sehingga mengakibatkan terjadinya kesimpangsiuran dan perbedaan pemahaman peraturan, tarikmenarik, saling berkontradiksi dan sebagainya.

Grey area perpajakan sering memunculkan perbedaan persepsi antara satu pihak dengan pihak lain, misal: antara otoritas pajak dengan pembayar pajak, antara pembayar pajak dengan pembayar pajak itu sendiri, atau bahkan diantara sesama pihak didalam otoritas pajak itu sendiri, yang mana dari kondisi itu akan berpeluang merugikan salah satu diantara beberapa pihak tersebut. 
Bagi Wajib Pajak kurangnya pemahaman terhadap grey area perpajakan dapat mempengaruhi jumlah $\mathrm{PPh}$ terutang yang harus dibayar. Suatu aturan sedianya tidak berpotensi menjadi objek pajak karena berada dalam wilayah abu-abu dapat dihitung dan dijadikan objek dalam penghitungan $\mathrm{PPh}$ perusahaan atau sebaliknya, hal tersebut dapat menyebabkan timbulnya potensi kerugian atau permasalahan perpajakan bagi Wajib Pajak. Potensi kerugian atau permasalahan perpajakan juga dapat timbul karena perbedaan penafsiran terhadap peraturan diantara sesama Wajib Pajak yang saling bertransaksi dan dapat juga terjadinya perbedaan penafsiran peraturan perpajakan antara Wajib Pajak dengan otoritas pajak dalam pemeriksaan atau penyidikan kewajiban perpajakan Wajib Pajak. Perbedaan penafsiran peraturan diantara Wajib Pajak yang saling bertransaksi dapat terjadi karena Wajib Pajak yang satu beranggapan bahwa transaksi yang sedang dilakukan merujuk pada suatu pasal dalam peraturan perpajakan sehingga terutang pajak sedangkan Wajib Pajak yang menjadi lawan bertransaksinya memiliki pemikiran yang berbeda, sehingga dari perbedaan tersebut dapat dimungkinkan terjadinya perselisihan karena salah satu diantaranya merasa dirugikan. Perbedaan penafsiran antara Wajib Pajak dengan otoritas pajak saat terjadinya pemeriksaan atau penyidikan kewajiban perpajakan Wajib Pajak dapat terjadi karena Wajib Pajak dalam melaksanakan kewajiban pajak sehari-harinya berdasar pada pasal/ayat pasal dalam peraturan perpajakan, sedangkan yang benar menurut otoritas pajak berdasarkan pada pasal/ayat pasal yang berbeda dari hal tersebut, sehingga perbedaan penafsiran tersebut dalam pemeriksaan pajak dapat melatarbelakangi terbitnya surat ketetapan pajak, antara lain surat ketetapan pajak lebih bayar (SKP-LB), surat ketetapan pajak nihil (SKP-N), surat ketetapan pajak kurang bayar (SKP-KB), surat ketetapan pajak kurang bayar tambahan (SKP-KBT) dan atau disertai dengan sanksi administrasi perpajakan sekaligus yang dapat berupa: bunga, denda, kenaikan atau juga dapat berupa sanksi pidana.

Tax planning melalui pemanfaatan grey area perpajakan memanfaatkan celah (loopholes) dalam peraturaan perpajakan yang berlaku, tetapi tetap dalam bingkai peraturan perpajakan yang ada (tax avoidance), sehinga antara keduanya adalah satu kesatuan yang saling melengkapi dan mendukung dalam pelaksanaanya, khususnya untuk mendukung penerapan tax managemen perusahaan dalam rangka pencapaian optimalisasi laba perusahaan sesuai dengan yang telah ditentukan, dalam kaitannya untuk menekan pembayaran pajak dan menghindari pengenaan sanksi administrasi oleh otoritas pajak terkait. Berdasarkan latar belakang, penulis tertarik untuk melakukan penelitian dengan judul "Implementasi tax planning melalui pemanfaatan grey area perpajakan untuk penghematan $\mathrm{PPh}$ terutang, study kasus pada Perusahaan X"

\section{TINJAUAN PUSTAKA}

Penelitian terkait sebelumnya, dilakukan oleh Indirawati (2005) dengan judul "Implementasi Tax Planning untuk Efisiensi PPh Terutang Pada PT.X". Variabel operasional yang digunakan dalam penelitian ini adalah pajak penghasilan, peraturan perpajakan dan perencanaan pajak. Tujuan dari penelitian ini adalah untuk menjelaskan bahwa pembuatan tax planning yang berdasar pada peraturan perpajakan yang berlaku, dapat dijadikan sebagai upaya dalam meningkatkan kewajiban perpajakan perusahaan secara efektif dan efisien, dan juga untuk mengetahui sejauh mana penerapan tax planning untuk meminimalkan beban pajak terutang sehingga mendorong optimalisasi laba perusahaan khususnya pada PT."X". Dari hasil penelitiannya diketahui bahwa PT."X" telah berupaya melaksanakan penerapan tax planning dengan benar untuk meminimalkan beban pajak yang dikeluarkan perusahaan, akan tetapi setelah ditinjau dari sudut pandang ilmiah, perencanaan pajak 
yang dilakukan perusahaan ternyata belum mencerminkan prinsip efisiensi dan efektifitas dalam pengelolaan sumber daya keuangan yang dimiliki, khususnya untuk pengeluaran beban pajak dan faktor-faktor yang menyertai beban tersebut, antara lain: biaya promosi, biaya perjalanan dinas, biaya tamu dinas, biaya sumbangan, penyisihan piutang raguragu serta kebijaksanaan untuk investasi dana dalam bentuk deposito.

Penelitian yang dilakukan oleh Rohmah (2008) dengan judul "Implikasi Zakat dalam Perencanaan Pajak". Permasalahan yang timbul dalam penelitian ini adalah bagaimanakah implikasi zakat dalam perencanaan pajak untuk meminimalkan beban pajak perusahaan dengan berdasarkan pada UU Nomor 17 Tahun 2000 tentang pajak penghasilan. Metode penelitian yang digunakan adalah metode kepustakaan (library reserch), metode dokumentasi (laporan keuangan perusahaan) dan metode lapangan (field research). Kesimpulan dari penelitian ini adalah penerapan zakat sebagai pengurang penghasilan kena pajak merupakan cara yang paling efisien dalam perencanaan pajak dan kesesuaiannya dengan visi perusahaan yang bernuansakan islami.

\subsection{Grey Area Perpajakan}

Idealnya, peraturan yang baik termasuk peraturan perpajakan adalah peraturan yang tidak mengandung grey area. Namun demikian, hal itu tidak mungkin dicapai karena manusia pasti mempunyai kelemahan dan juga memiliki perbedaan dalam banyak hal, termasuk perbedaan kepentingan antara satu pihak dengan pihak yang lain. Grey area dalam perpajakan sering mengakibatkan munculnya perbedaan persepsi antara satu pihak dengan pihak yang lainnya (misalnya antara otoritas pajak dengan pembayar pajak, diantara sesama pembayar pajak itu sendiri, atau bahkan antara sesama pihak didalam otoritas pajak). Dari kondisi diatas, jelas akan berpeluang merugikan salah satu pihak. Untuk itu, diperlukan kesepahaman diantara berbagai pihak itu, berkaitan dengan cara pandang mereka terhadap suatu aspek perpajakan. Namun untuk itu, setiap pihak yang akan menginterpretasikan dan mencoba mencari solusi berkaitan dengan suatu kasus grey area, terlebih dahulu harus memahami aspek hukum secara umum, dan khususnya sistem hukum di Indonesia. Dalam hal ini, pemahaman yang paling mendasar adalah berkaitan dengan bagaimana cara yang tepat untuk mengaplikasikan suatu ketentuan perpajakan. Selain faktor inherent diatas, grey area perpajakan juga dapat muncul karena sebab-sebab antara lain (Binsarjono, 2008:32):

1. Ketiadaan ketentuan yang semestinya mengatur suatu permasalahan, sehingga memunculkan berbagai persepsi atau interpretasi dan penafsiran.

2. Peraturan yang ada tidak jelas dan tidak pasti.

3. Peraturan yang ada berlebih atau saling tumpang tindih.

4. Perbedaan kepentingan dan penafsiran antara pembayar pajak dan otoritas pajak.

5. Perbedaan kepentingan dan penafsiran diantara pembayar pajak, dan

6. Perbedaan kepentingan dan penafsiran diantara berbagai pihak di dalam otoritas pajak.

\subsection{Grey Area di dalam Peraturan Pajak Penghasilan (PPh)}

Sesuai dengan isi Undang-Undang Republik Indonesia Nomor 36 Tahun 2008 tentang perubahan keempat atas UndangUndang Nomor 7 Tahun 1983, Pasal 4 (1) pajak penghasilan adalah pajak yang dikenakan pada setiap tambahan kemampuan ekonomis yang diterima atau diperoleh oleh Wajib Pajak, baik yang berasal dari Indonesia maupun dari luar Indonesia, yang dapat dipakai untuk konsumsi atau untuk menambah kekayaan Wajib Pajak yang bersangkutan, dengan nama dan dalam bentu apapun. Dari makna "setiap tambahan kemampuan ekonomis" diatas, pajak 
penghasilan memiliki makna yang luas, makna tersebut dijelaskan pada pasal demi pasal dalam ketentuan tersebut, diantaranya yang sering kita jumpai dalam kewajiban perpajakan sehari-hari adalah pengenaan pajak penghasilan perusahaan (PPh Badan), pajak penghasilan pasal $21 \quad(\mathrm{PPh} 21)$, pajak penghasilan pasal 23/26/Final (PPh 23/26/Final) dll. Grey area perpajakan pada peraturan pajak penghasilan $(\mathrm{PPh})$, diantaranya dapat kita temui juga dalam aturan

1. Grey area pada aturan pengenaan $\mathrm{PPh}$ Badan perusahaan, antara lain:

a. Masalah taxability suatu penghasilan.

b. Meminjam nama perusahaan lain ketika bertransaksi (pinjam bendera).

c. Selisih atas kurs deposito atau piutang valas.

d. Masalah deductibility pengeluaran.

e. Dokumentasi biaya promosi.

f. Kupon makan.

g. Pajak daerah.

h. Sanksi pajak daerah.

i. Biaya penagihan pajak.

j. Harta menurut pajak dibandingkan dengan harta menurut akuntansi.

k. Pengelompokan harta.

1. Aspek pajak atas goodwill

m. Bonus karyawan yang dihitung dari laba tahun lalu.

n. Pengaruh rugi selisih kurs pada angsuran PPh Pasal 25.

o. Menentukan tes waktu untuk BUT (Fisik atau Kontrak).

2. Grey area pada aturan pengenaan $\mathrm{PPh}$ Pasal 21, antara lain:

a. Direksi tidak digaji oleh perusahaan.

b. Ekspatriat digaji dibawah standar.

c. Gross up PPh Pasal 21 tidak konsisten.

d. Karyawan daerah dipotong di pusat (tempat terutang).

e. Pemotongan PPh 21 terhadap sekutu firma.

3. Grey area pada aturan pengenaan $\mathrm{PPh}$ Pasal 23/26/Final(4 ayat 2), antara lain:

a. Gross up PPh Pasal 23 sepihak. b. Kontrak bagi hasil tanpa join operation.

c. Kredit konsumen dibanding dengan financial lease.

d. Pemotongan PPh Pasal 26 atas penghasilan diluar P3B.

e. Sewa ruangan hotel untuk kantor.

f. Sewa kendaraan dibanding dengan ongkos angkut.

g. Sewa gudang dibandingkan dengan jasa penyimpanan.

h. Pemotongan PPh atas jasa cleanning service.

i. Pemotongan $\mathrm{PPh}$ atas jasa outsourcing.

j. Pemotongan $\mathrm{PPh}$ atas jasa maklon.

k. SHU dibandingkan dengan Simpanan anggota koperasi.

1. BUT aktivitas dan $\mathrm{PPh}$ Pasal 26 (sudah ber-NPWP dibanding dengan belum ber-NPWP.)

$\mathrm{m}$. Komisi/Bonus dibanding dengan Diskon/Margin.

\subsection{Tax Planning}

Pajak merupakan beban yang dapat mengurangi laba bersih perusahaan (Suandy,2001:2). Dilihat dari sudut pandang ekonomi, pajak merupakan pemindahan sumber daya dari sektor privat (perusahaan) ke sektor publik (pemerintah), yang mana pemindahan sumber daya tersebut akan mempengaruhi daya beli (purchasing power) atau kemampuan belanja (spending power) sektor privat. Karenanya, agar perusahaan dapat memperoleh laba bersih yang diharapkan, maka keputusan bisnis yang akan diambil perusahaan sebaiknya dapat mempertimbangkan faktor-faktor pajak yang menyertainya. Dan agar tidak terjadi beban dikemudian hari karena ketidak patuhan dalam pemenuhan kewajiban perpajakan Wajib Pajak, maka kewajiban perpajakan perusahaan harus dikelola dengan baik juga.

Pengelolaan kewajiban perpajakan Wajib Pajak badan sering dianalogikan sebagai elemen pengatur manajemen dalam suatu perusahaan, atau yang sering disebut 
dengan Manajemen Pajak. Secara umum, manajemen pajak adalah sarana atau alat yang dapat digunakan untuk memenuhi kewajiban perpajakan dengan benar tetapi jumlah pajak yang harus dibayar dapat ditekan seminimal mungkin agar dapat memperoleh laba dan likuiditas yang diharapkan (Suandy,2001:7). Tujuan dari manajemen pajak, secara spesifikasi dapat dibagi menjadi dua, antara lain: 1) Menerapkan peraturan perpajakan secara benar, dan 2) Usaha efisiensi untuk mencapai laba dan likuiditas yang seharusnya. Tujuan tersebut dapat diimplementasikan melalui fungsi-fungsi manajemen pajak seperti berikut:

1. Perencanaan Pajak (tax planning)

2. Pelaksanaan Kewajiban Perpajakan (tax implementation)

3. Pengendalian Pajak (tax control)

Perencanaan pajak adalah langkah awal dalam manajemen pajak. Pada tahap ini dilakukan pengumpulan dan penelitian terhadap peraturan perpajakan, dengan maksud dapat diseleksi jenis tindakan penghematan pajak yang dapat dilakukan. Secara umum, perencanaan pajak merujuk kepada proses perekayasaan usaha dan transaksi Wajib Pajak supaya hutang pajaknya berada dalam jumlah yang minim tetapi masih dalam bingkai peraturan perpajakan yang berlaku. Cara meminimalkan besarnya beban pajak yang harus dibayar, dapat dilakukan melalui beberapa cara, diantaranya: 1) Upaya penghindaran atau memperkecil pembayaran pajak, tetapi tetap masih berada dalam bingkai peraturan perpajakan (tax avoidance), dan

Upaya penghindaran atau memperkecil pembayaran pajak tetapi bertentangan/ melanggar peraturan perpajakan yang berlaku (tax evasion). Penerapan tax evasion berisiko menimbulkan pemborosan sumber daya perusahan (timbulnya sanksi denda, bunga dan kenaikan) jika ketahuan. Untuk itu perencanaan pajak perlu dilakukan agar perencanaan yang telah dilakukan dapat dilaksanakan secara lengkap, benar, tepat waktu dan tetap masih dalam bingkainya, sehingga dapat menghindari timbulnya pemborosan sumber daya perusahaan.

Sistem perpajakan menganut prinsip substansi mengalahkan bentuk formal (substance over form rule). Artinya walaupun perusahaan telah memenuhi kewajiban perpajakan secara formal, tetapi jika ternyata substansi menunjukkan lain atau motivasi rekayasa tidak sesuai dengan jiwa dari ketentuan perpajakan, maka otoritas pajak (fiskus) dapat menggangap bahwa Wajib Pajak kurang patuh dalam memenuhi kewajiban perpajakannya. Apabila terjadi perbedaan interpretasi fakta perpajakan, maka lembaga peradilan pajak yang akan memutuskan. Beberapa hal yang perlu diperhatikan dalam membuat perencanaan pajak (Suandy,2001:10):

1. Tidak melanggar ketentuan perpajakan: Bila suatu perencanaan pajak (tax planning) ingin dipaksakan dengan melanggar ketentuan perpajakan, untuk Wajib Pajak merupakan resiko (tax risk) yang sangat berbahaya dan mengancam keberhasilan perencanaan pajak (tax planning) tersebut.

2. Secara bisnis masuk akal: Perencanaan pajak merupakan bagian yang tidak terpisahkan dari perencanaan menyeluruh (global strategy) perusahaan baik jangka panjang maupun jangka pendek, maka perencanaan pajak (tax planning) yang tidak masuk akal akan memperlemah perencanaan itu sendiri.

3. Bukti-bukti pendukung yang tersedia memadai, misalnya: dukungan perjanjian (agreement), faktur (invoice) dan juga perlakuan akuntansinya (accounting treatment).

Beberapa hal yang dapat dilakukan untuk mencapai tujuan manajemen pajak, antara lain:

1. Memahami ketentuan peraturan perpajakan: dengan mempelajari peraturan perpajakan seperti Undang-Undang, Keputusan Presiden, Keputusan Menteri Keuangan, Keputusan Dirjen Pajak, dan 
Surat Edaran Dirjen Pajak kita dapat mengetahui peluang-peluang yang dapat dimanfaatkan untuk menghemat beban pajak.

2. Menyelenggarakan pembukuan yang memenuhi syarat. Pembukuan merupakan sarana yang sangat penting dalam penyajian informasi keuangan perusahaan yang disajikan dalam bentuk laporan keuangan dan menjadi dasar dalam menghitung besarnya jumlah pajak terutang.

\subsection{Implementasi Tax Planning}

Setelah tahap demi tahap dalam pembuatan tax planning telah diketahui, serta faktor yang dapat dimanfaatkan dalam melakukan penghematan pajak juga bisa diketahui, Maka langka selanjutnya adalah mengimplementasikannya baik secara formal maupun material (Suandy, 2001:10). Menurut Splitz (1983) dalam bukunya International Tax Planning, seperti telah dikutip oleh Suandy (2001:14-27), agar perencanaan pajak yang telah dibuat dapat membuahkan hasil sesuai dengan yang diharapkan, maka perencanaan itu harus dilakukan melalui tahapan seperti berikut:

1. Menganalisis informasi yang tersedia.

2. Mendesain satu atau lebih kemungkinan model perencanaan pajak.

3. Mengevaluasi model-model perencanaan pajak yang telah didesain.

4. Mencari kelemahan dan memperbaiki kembali perencanaan pajak.

5. Memutakhirkan perencanaan pajak.

\subsection{Hubungan Grey Area Perpajakan dengan Tax Planning}

Grey area perpajakan adalah wilayah abu-abu yang berpotensi ditafsirkan berbeda oleh banyak orang. Tidak dapat dipungkiri bahwa peraturan perpajakan yang ada dan berlaku saat ini di Indonesia masih banyak terdapat grey area. Kemampuan dalam mengartikan dan memahami grey area perpajakan dengan tetap berdasar pada ketentuan peraturan perpajakan yang ada dengan baik, dapat menyebabkan Wajib Pajak terhindar dari pemborosan dalam penggunaan sumber daya keuangan perusahaan. Untuk itu pemahaman grey area perpajakan yang matang pada saat pembuatan tax planning akan menghasilkan penghematan dalam penggunaan sumber daya keuangan perusahaan, khususnya dalam hal pembayaran pajak terutang, yang pada akhirnya dapat mencapai tujuan perusahaan yakni perolehan laba yang diharapkan. Tax planning melalui pemanfaatan grey area perpajakan berusaha memanfaatkan celah (loopholes) dalam peraturaan perpajakan yang berlaku, tetapi tetap dalam bingkai peraturan perpajakan yang ada (tax avoidance), sehinga antara keduanya adalah satu kesatuan yang saling melengkapi dan mendukung dalam pelaksanaanya. khususnya untuk mendukung penerapan tax managemen perusahaan dalam rangka pencapaian laba perusahaan sesuai dengan yang telah ditentukan.

\subsection{Hubungan Tax Planning dengan Efisiensi Pembayaran Pajak}

Pajak merupakan salah satu unsur yang akan mengurangi perolehan keuntungan perusahaan, maka dapat dipahami apabilah Wajib Pajak akan berusaha untuk membayar pajaknya secara efektif dan efisien dalam rangka mengoptimalkan perolehan keuntungan yang telah didapatnya. Cara yang dapat dilakukan Wajib Pajak adalah melalui pengendalian dan perencanaan pajak (tax planning). Penerapan tax planning yang baik, benar dan tepat waktu akan berpengaruh bagi perusahaan untuk penghematan biaya pajak. Dengan penerapan tax planning yang sesuai dengan ketentuan perpajakan yang berlaku, maka perusahaan akan terhindar dari pemborosan sumber daya yang dimilikinya (Suandy,2001:2), serta perusahaan juga dapat terhindar dari sanksi administrasi perpajakan, baik berupa bunga, dend, kenaikan pajak maupun pidana. Selain itu perusahaan juga mampu melalukan estimasi biaya pajak yang 
akan dikeluarkan, sehingga pengaturan arus kas perusahaan akan menjadi lebih baik.

\subsection{Pengaruh Pajak Terhadap Perusahaan}

Pajak merupakan pungutan yang dilakukan oleh pemerintah, dimana sebagian hasilnya akan digunakan pemerintah untuk penyediaan barang dan jasa publik. Karena pajak yang akan dibayar oleh perusahaan mengakibatkan adanya arus keluar sumber daya, maka dalam praktik bisnis pajak tersebut umumnya dianggap sebagai biaya atau beban (expanse) usaha yang akan mempengaruhi (mengurangi) laba perusahaan. Karena adanya anggapan pajak sebagai biaya tersebut, maka perusahaan akan berupaya untuk meminimalkan beban itu agar laba yang diperoleh, pengembalian investasi, dan arus kas perusahaan menjadi optimal. Upaya tersebut sering disebut sebagai manajemen pajak (tax manajemen). Manajemen pajak merupakan strategi penghematan pajak yang tujuannya bukan untuk mengelak membayar pajak, tetapi mengatur sehingga pajak yang dibayar tidak lebih atau kurang dari jumlah yang seharusnya (Sudibyo,2004:3). Bagi perusahaan, pajak merupakan biaya yang jika pengelolaanya tidak dilakukan dengan baik, akan berakibat buruk bagi perusahaan karena akan mempengaruhi laba (profit margin) sedangkan pajak sebagai distribusi laba akan mempengaruhi rate of return on investment dan berpengaruh terhadap kebijakan pembagian dividen (Suandy,2001:6).

\section{METODE PENELITIAN}

\subsection{Jenis Penelitian}

Pendekatan dalam penelitian ini adalah kualitatif dengan metode study kasus. Pendekatan kualitatif memberikan penekanan pada penyusunan teori melalui pengungkapan fakta, sedangkan metode study kasus berusaha mengungkapkan karakteristik masalah yang berkaitan dengan latar belakang kondisi saat ini dari subjek yang diteliti, serta interaksinya dengan lingkungan dalam penelitiannya

(Indriantoro

dan Supomo,2002:26).

\subsection{Teknik Pengambilan Data}

Teknik pengambilan data dalam penelitian ini dilakukan dengan cara penelitian lapangan (field research) yaitu pengumpulan data dengan cara melakukan penelitian langsung pada objek. Data yang diambil antara lain:

1. Wawancara (interview): Dilakukan kepada pihak terkait dalam perusahaan (bagian akuntansi, keuangan, dan perpajakan) dengan maksud untuk memperoleh data sebagai bahan untuk melakukan konstruksi kejadian dan mencari informasi yang dibutuhkan dalam perusahaan khususnya mengenai kebijakan terhadap grey area perpajakan dan tax planning yang telah diterapkan oleh perusahaan selama ini.

2. Dokumenter: Data yang diambil dalam penelitian ini adalah data dokumentasi berupa laporan keuangan atau catatan akuntansi yang ada pada perusahaan.

\subsection{Definisi Operasional Variabel}

Variabel operasional yang digunakan sebagai konstruk dalam penelitian ini adalah:

\subsubsection{Pajak Penghasilan}

Pajak penghasilan yang dimaksudkan dalam variabel ini, yaitu: Iuran rakyat kepada kas negara berdasarkan Undang-Undang Nomor 36 Tahun 2008 yang dapat dipaksakan dengan tidak memberikan jasa timbal balik (kontra prestasi), dan yang langsung dikenakan pada setiap tambahan kemampuan ekonomis yang diterimah atau diperoleh oleh Wajib Pajak, baik yang berasal dari Indonesia maupun dari luar Indonesia, yang dapat dipakai untuk konsumsi atau menambah kekayaan Wajib Pajak yang bersangkutan, dan yang digunakan untuk membiayai pengeluaran umum.

\subsubsection{Ketentuan Peraturan Perpajakan yang Berlaku}


Ketentuan peraturan perpajakan yang dimaksud dalam variabel penelitian ini, adalah: landasan hukum yang mengatur sistem dan mekanisme pemungutan pajak di Indonesia, yang berupa Undang-Undang perpajakan, serta produk hukum yang berada dibawahnya: Peraturan Pemerintah, Keputusan Menteri Keuangan, Keputusan Direktorat Jenderal Pajak, Surat Edara Direktorat Jenderal Pajak dll.

\subsubsection{Grey Area Perpajakan}

Grey area perpajakan yang dimaksudkan dalam variabel ini, adalah: suatu keadaan, transaksi, atau kejadian yang dicurigai atau diindikasikan akan terekspos oleh peraturan perpajakan, akan tetapi tidak ada peraturan perpajakan yang berlaku saat ini yang dapat diterapkan terhadap hal tersebut. Pemanfaatan grey area perpajakan dengan tetap berada dalam bingkai peraturan perpajakan yang berlaku, diharapkan bisa meminimalkan beban $\mathrm{PPh}$ terutang perusahaan untuk mendapatkan laba usaha yang optimal.

\subsubsection{Perencanaan Pajak (Tax Planning)}

Perencanaan pajak yang dimaksud dalam variabel penelitian ini, adalah: upaya melakukan manipulasi penghasilan Wajib Pajak secara legal sesuai dengan ketentuan peraturan perpajakan untuk memperkecil jumlah pajak yang terutang (Tjahyono dan Hussain, 2000:475).

\subsection{Unit Analisis}

Unit analisis dalam penelitian ini adalah melakukan analisis terhadap peraturan pajak penghasilan, melakukan identifikasi dan memetakan apakah dari aturan tersebut terdapat grey area atau tidak, menganalisis potensi risiko yang ditimbulkan dan menyusun konstruk dalam pembuatan tax planning. Setelah itu melakukan implementasi tax planning tersebut dalam setiap aktivitas transaksi operasional perusahaan, dan tax planning yang telah dibuat ditujukan untuk menghemat seminimal mungkin beban pajak yang dikeluarkan oleh perusahaan, untuk mendapatkan laba usaha yang diharapkan.

\subsection{Teknik Analisis Data}

Analisis data dilakukan secara kualitatif (non statistika), dengan membaca tabel atas angka yang ada, melakukan penjabaran dan interpretasi serta melakukan wawancara untuk menggali informasi guna penyusunan kerangka konstrusi suatu kejadian. Setelah hal ini selesai dilakukan, langka selanjutnya adalah:

1. Melakukan identifikasi semua data terkumpul dan selanjutnya menguji tingkat validitas, reliabilitas, dan obyektivitas data yang ada sebelum di proses lebih lanjut. Uji validitas dan reliabilitas data dalam penelitian ini dilakukan melalui Uji Credibility, Uji Transferability, Uji Depenability, dan Uji Konfirmability.

2. Memahami ketentuan undang-undang PPh Nomor 36 Tahun 2008 serta melakukan identifikasi satu persatu isi dari undangundang tersebut terhadap kemungkinan ada atau tidaknya grey area perpajakan.

3. Melakukan identifikasi grey area perpajakan didalam aturan tersebut dan aturan pendukungnya serta mempertimbangkan kemungkinan risiko yang ditimbulkan jika diaplikasikan.

4. Membandingkan antara peraturan perpajakan yang berlaku dengan fakta yang diterapkan di perusahaan.

5. Membuat tax planning

a. Memasukkan grey area pada taxable income dan deductible expense pada penyusunan proyeksi tax planning perusahaan.

b. Membedakan antara deductible expense dan non deductible expense

c. Mentransformasikan non deductible expense menjadi deductible expense

d. Penamaan akun yang sesuai dengan ketentuan undang-undang

e. Menggambil kesimpulan dan memberikan saran kepada perusahaan.

4. ANALISIS DAN PEMBAHASAN 


\subsection{Uji Validitas dan Reliabilitas Data Penelitian}

Uji validitas dan reliabilitas adalah pengujian yang dilakukan sebelum melakukan analisis terhadap data penelitian yang didapat, pengujian tersebut dilakukan untuk memberikan keyakinan yang memadahi terhadap hasil penelitian yang telah dilakukan. Uji validitas dan reliabilitas yang dilakukan, antara lain:

1. Uji credibility (validitas Internal) adalah: pengujian tentang nilai kebenaran dari data yang didapat oleh peneliti dan dijadikan bahan bagi peneliti untuk melakukan kajian dan analisis data yang akan ditelitinya, yang berupa: data laporan laba-rugi perusahaan, data daftar harta perusahaan (inventaris kantor, kendaraan, gedung dll), data biaya penyusutan, SPT Tahunan PPh Badan perusahaan dll. Pengujian kredibilitas tersebut dilakukan melalui beberapa cara antara lain: melalui perpanjangan jangka waktu pengamatan, peningkatan ketekunan dalam penelitian, triangulasi, diskusi dengan teman sejawat, analisis kasus negatif, dan melakukan membercheck.

2. Uji transferability (validitas eksternal) adalah: pengujian tentang penerapan dari data yang didapat oleh peneliti, yakni memberikan uraian tentang data yang diterimanya secara rinci, jelas, sistematis, dan dapat dipercaya sehingga pembaca dapat memahami data yang ada didalam hasil penelitiannya dengan mudah, agar hasil dari penelitian yang telah dilakukan dapat diimplementasikan dengan baik. Pengujian transferability yang dilakukan peneliti dalam penelitian ini berupa data yang berkaitan dengan kebijakan akuntansi perusahaan, kebijakan tax planning perusahaan, laporan laba-rugi perusahaan dll.

3. Uji dependability (reliabilitas) adalah: pengujian tentang konsistensi dari data yang didapat peneliti yakni dengan cara melakukan penelitian lapangan (uji lapangan) terhadap sumber data yang digunakan dalam penelitian serta uji keabsahan data yang ada, yang mencakup data: laporan laba-rugi perusahaan, data aset (harta) berwujud yang dimiliki oleh perusahaan, kebijakan akuntansi yang diterapkan diperusahaan dll.

4. Uji konfirmability (obyektivitas): adalah pengujian tentang naturalitas dari data yang didapat oleh peneliti yakni, data yang digunakan dalam penelitian dapat dikonfirmasikan tentang kebenaran dan keabsahannya kepada pihak-pihak yang bersangkutan. Uji konfirmability hampir sama dengan langka yang dilakukan dalam pengujian dependability sehingga antara keduanya dapat dilakukan secara bersamaan. Uji konfirmability dalam penelitian ini dilakukan melalui pengujian dilapangan terhadap data-data yang ada (laporan laba-rugi, daftar harta, rincian beban penyusutan, kebijakan akuntansi, laporan SPT Tahunan PPh Perusahaan dll), serta melakukan konfirmasi secara langsung melalui wawancara dengan bagian terkait, antara lain dengan kepala bagian perpajakan perusahaan untuk menguji kebenaran data SPT Tahunan PPh Perusahaan yang diterima, dengan pimpinan di bagian akuntansi untuk menguji kebenaran data laporan laba-rugi dan beban penyusutan serta kebijakan akuntansi perusahaan, dan dengan pimpinan pada bagian pengelolaan aset dan kendaraan perusahaan untuk menguji kebenaran tentang data rincian aset tetap yang dimiliki perusahaan yang diterima oleh peneliti dll.

\subsection{Celah dalam Grey Area Peraturan Perpajakan yang sudah bisa dimanfaatkan dalam Pembuatan Tax Planning Perusahaan}

Setelah melakukan identifikasi dan mempelajari kebijakan perusahaan dalam pelaksanaan kewajiban perpajakan yang selama ini telah berjalan, peneliti melihat bahwa perusahaan telah memanfaatkan sebagian dari celah dalam grey area 
peraturan perpajakan dalam pembuatan tax planning perusahaan, pemanfaatan celah dalam grey area tersebut bermanfaat positif bagi perusahaan khususnya dalam mendapatkan penghematan pembayaran pajak dalam kaitannya untuk mendapatkan optimalisasi income after tax perusahaan. Berikut adalah celah dalam grey area peraturan perpajakan yang sudah bisa dimanfaatkan oleh perusahaan dalam kaitannya untuk mendapatkan optimalisasi income after tax adalah:

1. Celah dalam grey area pada ketentuan PPh badan perusahaan:

a. Celah dalam grey area peraturan perpajakan terkait dengan transaksi selisih atas kurs deposito atau piutang valas, dimana dari pemanfaatan celah tersebut perusahaan diuntungkan dengan terhindar dari koreksi fiskal positif atas pendapatan atau beban selisih kurs yang tercatat dalam laporan keuangan perusahaan.

b. Celah dalam grey area peraturan perpajakan atas transaksi terkait dengan deductibility pengeluaran, khususnya yang berkaitan dengan biaya untuk langganan koran dan majalah perusahaan, dimana dari pemanfaatan celah tersebut perusahaan diuntungkan dengan terhindar dari koreksi fiskal positif atas biaya berlangganan Koran dan majalah yang tercatat dalam laporan keuangan perusahaan.

c. Celah dalam grey area peraturan perpajakan tentang transaksi terkait dengan bonus karyawan yang dihitung dari laba tahun lalu, dimana dari pemanfaatan celah tersebut perusahaan diuntungkan dengan terhindar dari koreksi fiskal positif atas biaya pemberian bonus kepada karyawan atas pencapaian kinerja yang tercatat dalam laporan keuangan perusahaan.

2. Celah dalam grey area pada Ketentuan PPh Pasal 21 Perusahaan :

a. Celah dalam grey area peraturan perpajakan tentang transaksi terkait dengan gross up PPh Pasal 21 perusahaan yang dilakukan dengan tidak konsisten, dimana dari pemanfaatan celah tersebut perusahaan diuntungkan dengan terhindar dari koreksi fiskal positif atas biaya pemberian fasilitas berupa tunjangan $\mathrm{PPh}$ Pasal 21 kepada karyawan yang ditanggung oleh perusahaan.

Berdasarkan penjelasan diatas, peneliti menyimpulkan bahwa tax planning melalui pemanfaatan grey area pada peraturan perpajakan yang telah dilakukan perusahaan selama ini, telah mendapatkan penghematan pajak yang signifikan.

\subsection{Celah dalam Grey Area Perpajakan Perusahaan yang masih bisa dimanfaatkan dalam Pembuatan Tax Planning Perusahaan}

Setelah mengidentifikasi dan mempelajari kebijakan perusahaan dalam pelaksanaan kewajiban perpajakan perusahaan yang selama ini telah berjalan dibandingkan dengan aturan-aturan perpajakan yang berlaku, serta kemungkinan celah yang ada didalam grey area pada peraturan perpajakan yang masih bisa dimanfaatkan oleh perusahaan, peneliti dapat menjelaskan bahwa strategi tax planning perusahaan selama ini sudah berjalan dengan cukup baik, celah dalam wilayah abu-abu atas peraturan perpajakan yang ada sebagian besar sudah bisa diimplementasikan perusahaan melalui program tax planning, hanya saja masih terdapat sedikit kelemahan dalam kebijakan perusahaan tersebut yang masih bisa dijadikan bahan evaluasi bagi manajemen perusahaan untuk menentukan arah dalam merumuskan kebijakan tax planning dimasa yang akan datang untuk memperoleh penghematan pajak (tax saving), dalam kaitannya mendapatkan optimalisasi income after tax perusahaan. Berikut beberapa kebijakan perusahaan dibidang perpajakan yang bisa dijadikan bahan evaluasi bagi manajemen perusahaan 
untuk mendapatkan optimalisasi income after tax adalah:

1. Kelemahan/celah pada Ketentuan $\mathrm{PPh}$ Badan Perusahaan: Setelah melakukan analisis terhadap data yang ada, diketahui bahwa terdapat celah terkait pengelompokan golongan harta yang dimiliki perusahaan untuk keperluan penyusutan. Celah tersebut terkait dengan adanya perbedaan dalam pengelompokan jenis harta untuk keperluan penyusutan dalam laporan keuangan komersial perusahaan dengan ketentuan isi yang terdapat dalam Peraturan Menteri Keuangan No.96/PMK.03/2009. Selain itu, peneliti juga melakukan analisis terkait dengan pembelian inventaris kantor dengan nilai pembelian dibawah Rp2.500.000,00 yang memiliki umur ekonomis lebih dari satu tahun, langsung dibebankan sebagai biaya sekaligus oleh perusahaan sebagai biaya supplies kantor dalam laporan keuangannya. Kebijakan pembiayaan sekaligus tersebut berbeda dengan ketentuan Pasal 6 ayat 1 huruf $b$ dan Pasal 11 UU PPh Tahun 2008, sehingga harus dikoreksi fiskal positif. Selain perhitungan koreksi fiskal atas pembiayaan inventaris kantor tersebut, perusahaan juga harus menghitung koreksi fiskal negatif atas beban penyusutan inventaris kantor tersebut dalam tahun yang bersamaan. Berdasarkan penjelasan tersebut, peneliti menyimpulkan bahwa perusahaan dapat memperoleh penghematan koreksi fiskal atas biaya penyusutan dan pembelian inventaris kantor dibawah nilai 2.500.000. Penghematan pajak tersebut dapat terwujud jika kebijakan perusahaan terkait dengan penentuan golongan harta perusahaan sejalan dengan ketentuan tentang pengelompokan harta untuk keperluan penyusutan sesuai dengan Peraturan Menteri Keuangan Nomor 96/PMK.03/2009.

2. Kelemahan/celah pada Ketentuan $\mathrm{PPh}$ Pasal 21 Perusahaan: Setelah melakukan analisis terhadap data yang ada, diketahui bahwa perusahaan sudah melakukan kebijakan terkait dengan kewajiban $\mathrm{PPh}$ Pasal 21 dengan baik, sehingga ketentuan didalam peraturan $\mathrm{PPh}$ Pasal 21 sudah dapat dilaksanakan dengan baik sesuai peraturan yang ada.

3. Kelemahan/celah pada Ketentuan $\mathrm{PPh}$ Pasal 23/26/Final Perusahaan: Setelah melakukan analisis terhadap data yang ada, diketahui bahwa perusahaan sudah melakukan kebijakan terkait dengan kewajiban PPh Pasal 23/26/Final dengan baik, sesuai peraturan ada.

\section{SIMPULAN, SARAN DAN KETERBATASAN PENELITIAN}

\subsection{Simpulan}

Setelah melakukan analisis dan kajian atas pembahasan, penulis menarik kesimpulan hasil penelitian:

1. Implementasi tax planning perusahaan dilakukan dengan tetap berpedoman pada aturan perpajakan yang ada (tax avoidance) dan bukan sebaliknya (tax evasion).

2. Perusahaan telah menerapkan tax planning atas grey area pada ketentuan pajak penghasilan perusahaan terkait dengan transaksi selisih atas kurs deposito atau piutang valas, transaksi deductibility pengeluaran khususnya yang berkaitan dengan biaya untuk langganan koran dan majalah, transaksi bonus karyawan yang dihitung dari laba tahun lalu. Dimana dari implementasi tax planning tersebut perusahaan memperoleh manfaat berupa efisiensi pembayaran pajak penghasilan.

3. Terdapat grey area perpajakan yang belum bisa diimplementasikan dengan maksimal oleh Perusahaan dan memerlukan kajian lebih lanjut, yaitu kajian grey area atas pengelompokan jenis harta perusahaan untuk keperluan penyusutan dan pembebanan sekaligus pembelian inventaris kantor dibawah Rp. 2.500.000,00 
4. Upaya tax planning melalui pemanfaatan grey area perpajakan memiliki manfaat yang positif bagi perusahaan, khususnya untuk memaksimalkan income after tax.

\subsection{Saran}

Setelah melakukan analisis terhadap hasil penelitian, penulis memberikan saran perbaikan:

1. Perusahaan disarankan melakukan evaluasi secara terus menerus atas tax planning yang telah disusunnya secara periodik dan up date terhadap aturan perpajakan terbaru, agar mengetahui adanya perubahan dalam aturan perpajakan yang ada beserta implikasinya terhadap tax planning yang telah disusun.

2. Perusahaan disarankan melakukan evaluasi dan kajian secara periodik terhadap kebijakan yang telah dikeluarkan, khususnya terkait dengan kebijakan akuntansi dan perpajakan perusahaan. Kajian terhadap kebijakan yang ada akan memberikan pengaruh positif bagi perusahaan, untuk mendapatkan penghematan pembayaran pajak.

3. Perusahaan disarankan melakukan evaluasi terhadap kebijakan penentuan masa manfaat harta yang dimilikinnya untuk keperluan penyusutan, sebaiknya kebijakan tersebut sejalan dengan Peraturan Menteri Keuangan Nomor 96/PMK.03/2009 tentang pengelompokan harta untuk keperluan penyusutan agar meminalisir koreksi fiskal sehingga bisa mendapatkan penghematan pembayaran pajak.

4. Pengeluaran untuk pembelian inventaris kantor dengan nilai dibawah Rp2.500.000,00 yang memiliki masa manfaat lebih dari 1 tahun, sebaiknya pembebanan biayanya tetap melalui mekanisme penyusutan (depresiasi) dan bukan dibebankan sebagai biaya secara langsung, karena hal itu bisa berakibat adanya dampak perpajakan berupa koreksi fiskal.

\subsection{Keterbatasan Penelitian}

Penelitian ini dilakukan sesuai dengan prosedur ilmiah, namun memiliki bebarapa keterbatan antara lain:

1. Faktor yang mempengaruhi penghematan $\mathrm{PPh}$ terutang perusahaan dalam penelitian ini sebatas tax planning atas pemanfaatan grey area perpajakan, sedangkan masih banyak faktor lain yang mempengaruhi besarnya PPh terutang bagi perusahaan.

2. Penelitian ini adalah penelitian study kasus pada satu subjek penelitian saja, sehingga hasilnya belum dapat digeneralisasikan pada kelompok subjek lain yang lebih luas. akan tetapi subjek yang dipilih dianggap mewakili keseluruhan populasi yang ada.

\section{DAFTAR PUSTAKA}

1991, Keputusan Menteri Keuangan Republik Indonesia Nomor 1169 Tahun 1991 Tentang Kegiatan Sewa Guna Usaha (Leasing).

1997, Surat Edaran Direktur Jenderal

Pajak Republik Indonesia Nomor 03 Tahun 1997 Tentang Perlakuan Pajak Penghasilan Terhadap Selisih Kurs. 1998, Surat Direktur Jenderal Pajak Republik Indonesia Nomor 250 Tahun 1998 Tentang Perlakuan Pajak Penghasilan atas Keuntungan Selisih Kurs yang Berasal dari Deposito Berjangka dalam Dolar Amerika Serikat.

, 2000, Peraturan Pemerintah Republik Indonesia Nomor 138 Tahun 2000 Tentang Jenis Biaya atau Pengeluaran yang Tidak Diperkenankan untuk Dibiayakan dalam SPT Tahunan PPh. 2000, Keputusan Menteri Keuangan Republik Indonesia Nomor 466 Tahun 2000 Tentang Penyediaan Makanan dan Minuman untuk Karyawan atau Pegawai.

2000, Keputusan Menteri Keuangan Republik Indonesia Nomor 520 Tahun 
2000 s.t.d.d. Keputusan Menteri Keuangan Nomor 138 Tahun 2002 jo Peraturan Menteri Keuangan Nomor 96 Tahun 2009 Tentang Jenis-jenis Harta yang Termasuk dalam Kelompok Harta Berwujud Bukan Bangunan untuk Keperluan Penyusutan.

2000, Keputusan Menteri Keuangan Republik Indonesia Nomor 545 Tahun 2000 s.t.d.d. Peraturan Menteri Keuangan Republik Indonesia Nomor 15 Tahun 2006 Tentang Perlakuan atas Tunjangan Pajak

2001, Surat Direktur Jenderal Pajak Republik Indonesia Nomor 477 Tahun 2001 Tentang Perlakuan atas Selisih Kurs.

2001, Surat Direktur Jenderal Pajak Republik Indonesia Nomor 404 Tahun 2001 Tentang Penegasan Perhitungan Besarnya Angsuran PPh Pasal 25 dalam Hal Terdapat Penghasilan Tidak Teratur.

, 2002, Surat Edaran Direktur Jenderal Pajak Republik Indonesia Nomor 02 Tahun 2002 Tentang Perlakuan Pajak Penghasilan atas Pengeluaran untuk Pajak Daerah dan Retribusi Daerah. , 2002, Keputusan Menteri Keuangan Republik Indonesia Nomor 173 Tahun 2002 Tentang Standar Gaji Karyawan Asing. 2002, Keputusan Menteri Keuangan Republik Indonesia Nomor 85 Tahun 2002 s.t.d.d. Peraturan Menteri Keuangan Nomor 23 Tahun 2006 jo Keputusan Jenderal Pajak Nomor 459 Tahun 2002 Tentang Tata Cara Penyitaan Kekayaan Penanggung Pajak Berupa Piutang dalam Rangka Penagihan Pajak dengan Surat Paksa.. 2003, Surat Edaran Direktur Jenderal Pajak Republik Indonesia Nomor 14 Tahun 2003 Tentang Penyediaan Makanan dan Minuman untuk Karyawan atau Pegawai.

2003, Surat Direktur Jenderal Pajak Republik Indonesia Nomor 324 Tahun
2003 Tentang Perlakuan Selisih Kurs atas Deposito dalam Mata Uang Asing. 2004, Surat Direktur Jenderal Pajak Republik Indonesia Nomor 322 Tahun 2004 Tentang Penjelasan Tempat Kerja untuk Penyediaan Makanan dan Minuman untuk Karyawan atau Pegawai.

2007, UU Republik Indonesia Nomor 28 Tahun 2007 Tentang Perubahan Ketiga atas Undang-Undang Nomor 6 Tahun 1983 Tentang Ketentuan Umum dan Tata Cara Perpajakan.

2007, Peraturan Direktur Jenderal Pajak Republik Indonesia Nomor 70 Tahun 2007 Tentang Jenis Jasa lain dan Perkiraan Penghasilan Neto dalam Pajak Penghasilan.

2008, UU Republik Indonesia Nomor 36 Tahun 2008 Tentang Perubahan Keempat atas Undang-Undang Nomor 7 Tahun 1983 Tentang Pajak Penghasilan.

Binsarjono, Tugiman, 2008, Grey Area Perpajakan, Mitos atau Fakta?, Edisi Revisi, Penerbit Gemilang Gagasindo Handal, Jakarta.

Ilyas, Wirawan B. dan Burton, Richard, 2001, Hukum Pajak, Penerbit Salemba Empat, Jakarta.

Indriantoro, Nur dan Supomo,Bambang, 2002, Metodologi Penelitian Bisnis untuk Akuntansi dan Manajemen, Edisi pertama, Cetakan pertama, Buku I, Penerbit BPFE, Yogyakarta.

Indirawati, 2005, Implementasi Tax Planning untuk Efisiensi PPh Terutang Pada PT. " $X$ ", Gresik: Skripsi, Universitas Muhammadiyah Gresik.

Mardiasmo, 2003, Perpajakan, Edisi Revisi, Penerbit Andi, Yogyakarta.

Prabowo, Yusdianto, 2001, Akuntansi Pajak Terapan, Edisi Revisi, Penerbit Grasindo, Jakarta.

Rohmah, Lailatur N., 2008, Implikasi Penerapan Zakat dalam Perencanaan Pajak (Study Kasus Pada PT. BRI Syariah Tbk., Cabang Surabaya), 
Bangkalan : Skripsi, Universitas Sugiyono. 2007. Metode Penelitian Trunojoyo.

Suandy, Erly, 2000, Hukum Pajak, Edisi Pertama, Penerbit Salemba Empat, Jakarta.

Pendidikan (Pendekatan Kuantitatif, kualitatif, dan R\&D). Alfabeta, Bandung.

Suharsimi Arikunto. 2003. Manajemen Penelitian. Rineka Cipta, Jakarta.

Edisi Pertama, Penerbit Salemba Empat, Jakarta.

Sudibyo, 2004, Modul Manajemen Pajak (Tax Planning), Fakultas Ekonomi Universitas Airlangga, Surabaya. ono, Ahmad dan Husein, Fakhri M., 2000, Perpajakan, Edisi Revisi, Penerbit UPP AMP YKPN, Yogyakarta. 